\title{
KINERJA PERAWAT BERDASARKAN KOMITMEN PADA ORGANISASI DAN LINGKUNGAN KERJA PERAWAT
}

\author{
Muliyadi $^{12^{*}}$, Achir Yani S.Hamid ${ }^{3}$, Mustikasari ${ }^{3}$ \\ 1. Poltekkes Kemenkes Palembang, Sumatera Barat, Indonesia \\ 2. Program Studi Magister Fakultas Ilmu Keperawatan Universitas Indonesia, Depok 16424, Indonesia \\ 3. Fakultas Ilmu Keperawatan Universitas Indonesia, Depok 16424, Indonesia \\ *Email: muliyadiskp@yahoo.co.id
}

\begin{abstract}
Abstrak
Komitmen pada organisasi dan lingkungan kerja perawat merupakan faktor yang ada dalam pelayanan keperawatan di rumah sakit. Penelitian deskriptif dengan desain potong lintang bertujuan mendapatkan hubungan antara komitmen pada organisasi dan lingkungan kerja perawat dengan kinerja perawat pelaksana. Populasi penelitian adalah seluruh perawat pelaksana, dengan sampel adalah seluruh populasi yang memenuhi kriteria inklusi yaitu 107 perawat. Analisis melalui uji korelasi partial dan regresi linier ganda untuk analisis faktor dominan. Hasil penelitian terdapat hubungan signifikan komitmen pada organisasi dengan kinerja perawat pelaksana setelah dipengaruhi karakteristik perawat $(p=0,0005, \alpha=0,05)$. Lingkungan kerja berhubungan dengan kinerja perawat pelaksana setelah dipengaruhi karakteristik perawat $(\mathrm{p}=0,0005, \alpha=0,05)$. Komitmen afektif adalah faktor paling dominan berhubungan dengan kinerja perawat pelaksana.
\end{abstract}

Kata kunci: Kinerja Perawat Pelaksana, Komitmen pada Organisasi, Lingkungan Kerja

\begin{abstract}
Nurses' commitment on organization and nurse's working condition is an organizational factor in hospital nursing services. This study used descriptive design with cross sectional. The Purpose of the study was to describe the relationship between commitment to organization and nurses' working condition with the performance of nurse provider. The sample of this study was consisted of total population meeting the inclusive criteria of 107 nurses. Analysis of variable correlation utilized partial correlation test, for while analysis the determinant factor used multiple linear regression test. The result of the study showed that there was a significant relationship between commitment to organization with nurse provider's performance after affected by nurse's characteristics $(p=0,0005, \alpha=0,05)$. Nurses working condition had a significant relationship with the performance nurse providers after affected by the characteristic of nurses $(p=0,0005, \alpha=0,05)$. The most determinant factor related to nurse providers' performance was affective commitment.
\end{abstract}

Keyword: Commitment to Organization, Performance of Nurse's Provider, Work Condition

\section{Pendahuluan}

Tujuan pelayanan kesehatan adalah tercapainya kepuasan, harapan dan terpenuhinya kebutuhan pasien, tenaga pemberi layanan dan institusi. Pelayanan keperawatan memiliki peran yang besar dalam sistem pelayanan rumah sakit. Kualitas kinerja keperawatan menentukan kualitas pelayanan kesehatan di Rumah Sakit. Kinerja keperawatan diukur berdasarkan hasil pencapaian pelaksanaan standar kinerja dalam pelayanan keperawatan. PPNI (2004) merumuskan standar kinerja profesional keperawatan sebagai indikator kinerja keperawatan meliputi jaminan mutu, pendidikan, penilaian kinerja, kesejawatan, etik, kolaborasi, riset dan pemanfaatan sumber. Penelitian Departemen Kesehatan dan World Health Organization (2000) tentang kinerja perawat dan bidan di Provinsi Kalimantan Timur, Sumatera Utara, Sulawesi Utara, Jawa Barat dan DKI Jakarta menunjukan bahwa
$39,8 \%$ perawat melakukan tugas-tugas non keperawatan dan $47,4 \%$ perawat tidak memiliki uraian tugas secara tertulis.

Hasil analisis WHO (2003a) terhadap beberapa negara Asia termasuk Indonesia bahwa kinerja profesional perawat yang didasari oleh multidisiplinary learning terisolasi dari profesi kesehatan lainnya berdampak pada lemahnya peran yang saling mendukung diantara tenaga profesional kesehatan, kesulitan berkomunikasi, perawat memiliki pendekatan dan nilai yang berbeda dalam pelayanan kesehatan dengan yang lainnya, buruk dalam bekerjasama dan pendekatan yang terfragmentasi, persepsi yang berbeda antara perawat dan dokter, beberapa kesulitan dalam hubungan perawat dan manajemen. Kinerja perawat dalam pelayanan keperawatan di rumah sakit membutuhkan komitmen perawat yang kuat terhadap organisasi rumah sakit. 
Koentjoro (2007) menyatakan bahwa langkah awal membangun kinerja organisasi adalah membentuk komitmen dan kepedulian seluruh jajaran staf dalam organisasi. Penurunan komitmen organisasi menyebabkan kinerja buruk yang berdampak gagalnya pencapaian tujuan.

Kinerja perawat efektif memerlukan lingkungan kerja yang positif. Menurut National Study of the Changing Workforce (1997, dalam Robbins, 2003), faktor penting yang menimbulkan seseorang untuk menyukai pekerjaan dan tetap bekerja pada suatu organisasi adalah mutu pekerjaan dan dukungan lingkungan kerja.

Hasil analisis lingkungan kerja perawat oleh World Health Organization (2003b) di beberapa negara Asia termasuk Indonesia menemukan bahwa lingkungan kerja perawat belum optimal seperti pendapatan perawat yang rendah, fasilitas kesehatan yang buruk dan tidak aman bagi staf perawat, rasio perawat pasien yang tidak optimal, hubungan kerja dalam tim kesehatan yang perlu penguatan, beberapa perawat mengalami kekerasan fisik, kurang perlindungan (safety) dalam pekerjaan, dan beberapa fasilitas bagi perawat yang tidak memuaskan.

Indikator layanan keperawatan yang belum optimal pada RS X seperti turn over tenaga perawat pada tahun 2007 sebesar 8,5\%. Sementara kepuasan pasien atas kinerja perawatan terdapat $42,3 \%$ kategori cukup. Beberapa aspek kinerja keperawatan yang belum menimbulkan kepuasan pasien antara lain kemampuan perawat untuk cepat tanggap $42,3 \%$, kemampuan memahami permasalahan pasien $46,1 \%$, perhatian perawat terhadap keluhan pasien 34,6\%. menunjukan 30,8\% perilaku caring tidak baik kemampuan komunikasi $52,5 \%$ perawat mengalami kendala dalam komunikasi. Sedangkan kajian terhadap kinerja dalam aspek mutu pelayanan $36,1 \%$ perawat tidak mengetahui programmutu layanan keperawatan, dari sejumlah perawat yang mengetahui program mutu $37,7 \%$ mengatakan program mutu layanan keperawatan tidak berjalan (Muliyadi, 2007). Berdasarkan Latar belakang di atas maka pertanyaan penelitian ini adalah adakah hubungan komitmen pada organisasi dan lingkungkan Kerja dengan kinerja perawat pelaksana.

\section{Metode}

Jenis Penelitian deskriptif korelasional dengan desain potong lintang. Populasi penelitian adalah seluruh perawat pelaksana di Rumah Sakit Tugu Ibu Cimanggis Depok, sampel penelitian adalah seluruh populasi yang memenuhi kriteria inklusi dengan besar sampel 107 perawat pelaksana. Pengumpulan data penelitian menggunakan kuesioner. Analisis korelasi parsial digunakan untuk menguji hubungan antar variabel dan Uji Regresi liner ganda digunakan untuk menentukan faktor dominan.

\section{Hasil}

\section{Hubungan Komitmen pada organisasi dengan Kinerja Perawat Pelaksana setelah dipengaruhi karateristik perawat}

Tabel 1. menunjukkan hubungan yang signifikan antara komitmen pada organisasi dengan kinerja perawat pelaksana setelah dipengaruhi karakteristik perawat ( $p=0,0005, \alpha=0,05)$, dengan kekuatan hubungan sedang dan berpola positif.

Tabel 1 Hubungan Komitmen Pada Organisasi dengan Kinerja Perawat Pelaksana Setelah dipengaruhi karakteristik perawat

\begin{tabular}{lcc}
\hline Variabel Independen & $\begin{array}{c}\text { Koefisien } \\
\text { Korelasi }(\mathbf{r})\end{array}$ & $\mathbf{p}$ \\
\hline Komitmen & $\mathbf{0 , 3 4 9}$ & $\mathbf{0 , 0 0 0 5}$ \\
Komitmen Afektif & 0,423 & 0,0005 \\
Komitmen Normatif & 0,316 & 0,001 \\
Komitmen & 0,139 & 0,162 \\
Berkesinambungan & & \\
\hline
\end{tabular}

Variabel dependen: Kinerja perawat pelaksana

Komitmen afektif dan normatif berhubungan secara signifikan dengan kinerja perawat pelaksana, sedangkan komitmen ber-kesinambungan tidak berhubungan (lihat diagram 1.).

\section{Hubungan Lingkungan Kerja Perawat dengan Kinerja Perawat Pelaksana di Rumah Sakit X Kota Depok setelah dipengaruhi karakteristik perawat}

Tabel 2 menunjukkan hubungan yang signifikan Lingkungan Kerja Perawat dengan kinerja perawat pelaksana setelah dipengaruhi karakteristik perawat $(p=0,0005 ; \alpha=0,05)$. 
Selain itu, didapat nilai $\mathrm{r}=0,527$ dengan kekuatan hubungan kuat dan berpola positif. Lingkungan kerja pada aspek manajemen, kepemimpinan dan budaya; kendali terhadap praktek berhubungan dengan kinerja perawat pelaksana, sedangkan kendali terhadap beban kerja dan sumber yang memadai tidak berhubungan (lihat diagram 2 .).

Tabel 2. Hubungan Lingkungan Kerja dengan Kinerja Perawat Pelaksana Setelah dipengaruhi karakteristik perawat

\begin{tabular}{lcc}
\hline \multicolumn{1}{c}{ Variabel Independen } & $\begin{array}{c}\text { Koefisien } \\
\text { Korelasi }(\boldsymbol{r})\end{array}$ & $\mathbf{p}$ \\
\hline Lingkungan Kerja & 0,527 & 0,0005 \\
$\begin{array}{l}\text { Manajemen, Kepemimpinan } \\
\text { dan Budaya }\end{array}$ & 0,477 & 0,0005 \\
$\begin{array}{l}\text { Kendali terhadap Beban } \\
\text { Kerja }\end{array}$ & 0,137 & 0,169 \\
Kendali Terhadap Praktik & 0,572 & 0,0005 \\
Sumber Yang Memadai & 0,090 & 0,366 \\
\hline
\end{tabular}

Variabel dependen: Kinerja perawat Pelaksana

\section{Faktor yang Paling Dominan Berhubungan dengan Kinerja Perawat Pelaksana}

Pada ketiga variabel yaitu komitmen afektif; kendali terhadap praktik dan manajemen, kepemimpinan, budaya dapat menjelaskan variasi pada variabel kinerja perawat sebesar 43,2\% (lihat tabel 3). Variabel komitmen afektif merupakan variabel yang paling dominan, yang berhubungan dengan kinerja perawat pelaksana.

\section{Pembahasan}

\section{Komitmen pada organisasi dan kinerja perawat pelaksana}

Komitmen yang tinggi menimbulkan loyalitas terhadap organisasi melalui penerimaan sasaran, nilai, kemauan, dan kesediaan untuk menjadi bagian dari organisasi serta memiliki keinginan untuk bertahan (Hatmoko, 2006). Hasil analisis hubungan komitmen pada organisasi dengan kinerja perawat pelaksana setelah dipengaruhi karakteristik perawat menunjukkan hubungan yang signifikan.

Komitmen individu pada organisasi merupakan suatu sikap kerja seseorang terhadap organisasi (Allen \& Meyer, 1997; Gibson, Ivancevich, \& Donelly, 1996; Robbins, 2003). Komitmen organisasi kuat menimbulkan dorongan, keinginan dan kemauan dalam diri seserong untuk melakukan suatu pekerjaan dengan segala upaya yang dimiliki dengan didasari internalisasi nilai-nilai, tujuan organisasi kedalam diri individu.

Menurut Meyer dan Allen (1991) Karyawan yang memiliki komitmen pada organisasi akan bekerja penuh dedikasi. Meyer et al. (1989) menemukan bahwa penurunan komitmen pada organisasi menyebabkan kinerja buruk dan berdampak pada gagalnya pencapaian tujuan. Farrell dan Paterson (1984) Lemahnya komitmen perawat pada organisasi berdampak pada buruknya kinerja perawat, turn over (McNeese-Smith, 2001).

Komitnen afektif, normatif dan berkesinambungan hasil penelitian menunjukkan hubungan yang signifikan antara komitmen afektif dan normatif dengan kinerja, tetapi komitmen berkesinambungan tidak berhubungan dengan kinerja. Menurut Meyer et al. (1989), penampilan kerja (job performance) pekerja dengan komitmen berkesinambungan lebih rendah dibandingkan pekerja dengan komitmen afektif.

Individu dengan komitmen afektif yang tinggi memiliki kedekatan emosional yang erat dengan organisasinya. Kim dan Mauborgne (dalam Allen \& Mayer, 1997) menyatakan bahwa individu dengan komitmen afektif yang tinggi akan lebih mendukung kebijakan perusahanan. Komitmen afektif memiliki hubungan erat dengan pengukuran hasil pekerjaan individu (Bycio, Hackett dan Allen; Sager \& Johnston dalam Allen \& Meyer, 1997).

Individu dengan komitmen normatif yang tinggi akan bertahan dalam organisasi karena merasa adanya suatu kewajiban atau tugas. Menurut Allen dan Meyer (1997), perasaan adanya kewajiban dan tugas akan memotivasi individu untuk berkinerja secara baik dan melakukan tindakan tepat bagi organisasinya.

Tabel 3. Model Kinerja Perawat Pelaksana

\begin{tabular}{lcccc}
\hline \multicolumn{1}{c}{ Variabel } & B & Sig & $\begin{array}{c}\boldsymbol{R} \\
\text { square }\end{array}$ & $\mathbf{p}$ \\
\hline Constan & $-10,536$ & & & \\
Komitmen Afe ktif & 1.928 & 0,001 & & \\
$\begin{array}{l}\text { Manaje men } \\
\text { Kepe mimpinan, }\end{array}$ & 0,867 & 0,015 & 0,432 & 0,0005 \\
$\begin{array}{l}\text { Budaya } \\
\text { Kendali Terhadap }\end{array}$ & 1.373 & 0,0005 & & \\
Praktik & & & & \\
\hline
\end{tabular}


Komitmen normatif mempunyai hubungan positif dengan tingkah laku dalam pekerjaan seperti penampilan kerja, suasana pekerjaan (Allen \& Meyer, 1997). Komitmen normatif berhubungan dengan pengukuran hasil kerja, namun hubungan komitmen normatif dengan tingkah laku pekerja diluar perannya lebih lemah dibandingkan individu dengan komitmen afektif (Randall et al., dalam Allen \& Meyer 1997).

\section{Lingkungan Kerja Perawat dan Kinerja Perawat Pelaksana}

Lingkungan kerja merupakan salah satu faktor yang berada dalam organisasi yang memberikan pengaruh langsung pada aktivitas kerja setiap individu. Lingkungan kerja yang kondusif menciptakan kenyamanan dan kehidupan kerja yang lebih baik. Lingkungan kerja yang memuaskan menimbulkan keterikatan perawat pada rumah sakit yang merupakan faktor yang menentukan kualitas perawatan pasien (Schmalenberg, et al., 2008).

Kepuasan terhadap lingkungan kerja bagi staf keperawatan dalam suatu rumah sakit adalah sesuatu yang essensial dalam kualitas perawatan pasien (Schmalemberg \& Kramer, 2008). Lingkungan kerja keperawatan mempengaruhi perawat dan pasien (Aiken, et al., 2002; Vahey, et al., 2004 dalam McGillis, 2008).
Penelitian Sujarwati (2004) menjelaskan bahwa lingkungan kerja memiliki hubungan dengan pelaksanaan tugas pokok keperawatan. Hasil analisis hubungan aspek lingkungan kerja menunjukkan bahwa terdapat hubungan yang signifikan antara manajemen, kepemimpinan dan budaya dengan kinerja perawat pelaksana. Organisasi dan sistem kepemimpinan merupakan salah satu kunci pencapaian dari kualitas kerja (CCHSA, 2004).

Manajer memberikan pengaruh pada hasil yang dihasilkan oleh para staf. Kepemimpinan seorang manajer keperawatan merupakan faktor kunci yang mempengaruhi kepuasan kerja perawat dan retensi, serta terdapat hubungan antara kepemimpinan dan kualitas perawatan pasien serta efektifitas kerja staf keperawatan (McGillis, et al., 2003).

Hasil analisis menunjukkan tidak ada hubungan yang signifikan antara kendali beban kerja dengan kinerja perawat pelaksana. Beban kerja menggambarkan jumlah atau volume pekerjaan dibandingkan dengan waktu yang tersedia (Ilyas, 2004).

Peningkatan beban kerja perawat berdampak pada stress kerja perawat yang pada akhirnya berdampak pada ukuran kinerja dalam layanan keperawatan. Penelitian Shaver (2003) didapatkan bahwa perawat dengan beban kerja berlebih berpengaruh pada pencapaian kepuasan dan kualitas kerja.

Diagram 1. Hubungan Komitmen pada Organisasi dengan Kinerja Perawat Pelaksana

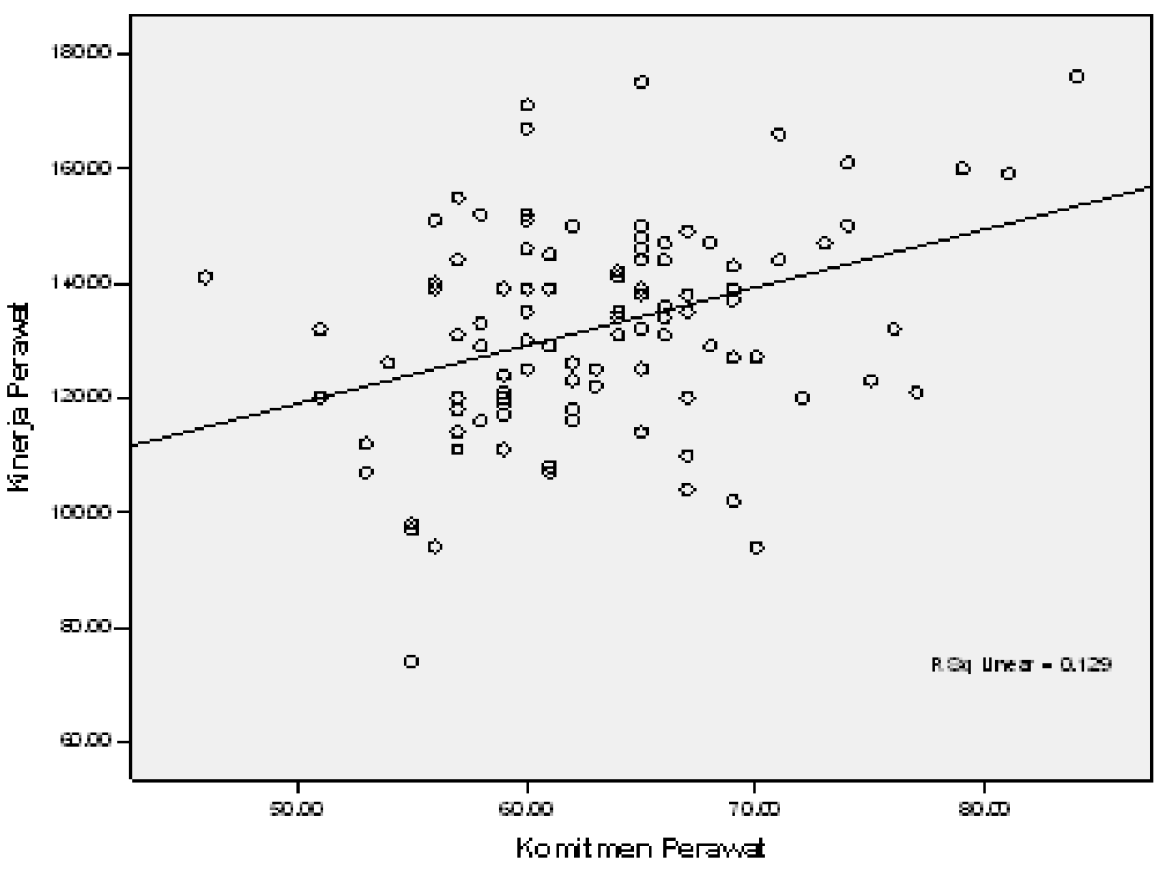


Gillies (1994) menjelaskan beban kerja di rumah sakit diukur dengan mempertimbangkan komponen sensus pasien, tingkat ketergantungan, rata-rata lama hari rawat, jenis kegiatan keperawatan dan rata-rata waktu yang dibutuhkan. Metode yang digunakan dalam pelayanan memiliki pengaruh terhadap beban kerja, pelayanan yang mengedepankan tugas atau fungsional, orientasi pelayanan yang didasarkan pada tugas relatif kurang tepat untuk menggambarkan beban kerja asuhan yang seharusnya dapat diukur dalam pelayanan keperawatan, sehingga persepsi beban kerja tidak dapat menggambarkan kualitas kinerja perawat.

Hasil analisis menunjukkan adanya hubungan kendali terhadap praktik dengan kinerja perawat pelaksana. Keperawatan merupakan profesi mandiri yang didasarkan atas ilmu dan kiat keperawatan. Praktik keperawatan memiliki karakteristik kewenangan, akontabilitas, pengambilan keputusan mandiri, kolaborasi, advocacy dan fasilitator. Menurut Kramer dan Schmalenberg (2004), Otonomi staf keperawatan sebagai bagian penting dari kendali terhadap praktik merupakan determinan kepuasan kerja, retensi, produktifitas dan kualitas pelayanan keperawatan.

Hasil analisis hubungan menunjukkan sumber yang memadai tidak berhubungan dengan kinerja perawat pelaksana. Pelayanan keperawatan merupakan aktivitas pelayanan yang dilaksanakan melalui upaya pemanfaatan sumber daya secara efektif.

Sumber daya terdiri dari sumber daya manusia dan sumber daya non manusia seperti alat, sistem, uang (Ilyas, 2004). Lowe (2002) menyampaikan indikator dalam sumber yang adekuat meliputi indikator suplai dan peralatan dan pengembangan profesional.

\section{Faktor Dominan yang Berhubungan dengan Kinerja Perawat Pelaskana}

Hasil analisis menunjukkan faktor personal (indvidu) perawat dalam hal ini komitmen afektif merupakan faktor determinan utama yang mempengaruhi kinerja perawat. Hal ini bersesuaian dengan pendapat Koentjoro (2007) yang menyatakan bahwa hal utama yang harus diupayakan dalam membangun kinerja yang baik adalah memumbuhkan komitmen setiap individu dalam organisasi. Dengan demikian secara teoritis, varibel yang paling mungkin diintervensi untuk meningkatkan kinerja adalah menumbuhkan komitmen perawat pelaksana.

Kendali terhadap praktik merupakan variabel lainnya yang memberikan pengaruh pada kinerja perawat. Kendali terhadap praktik didasarkan pada wewenang dan tanggung jawab yang diiringi oleh legal aspek yang berhubungan dengan praktik keperawatan.

Diagram 2. Hubungan Lingkungan Kerja Perawat dengan Kinerja Perawat Pelaksana

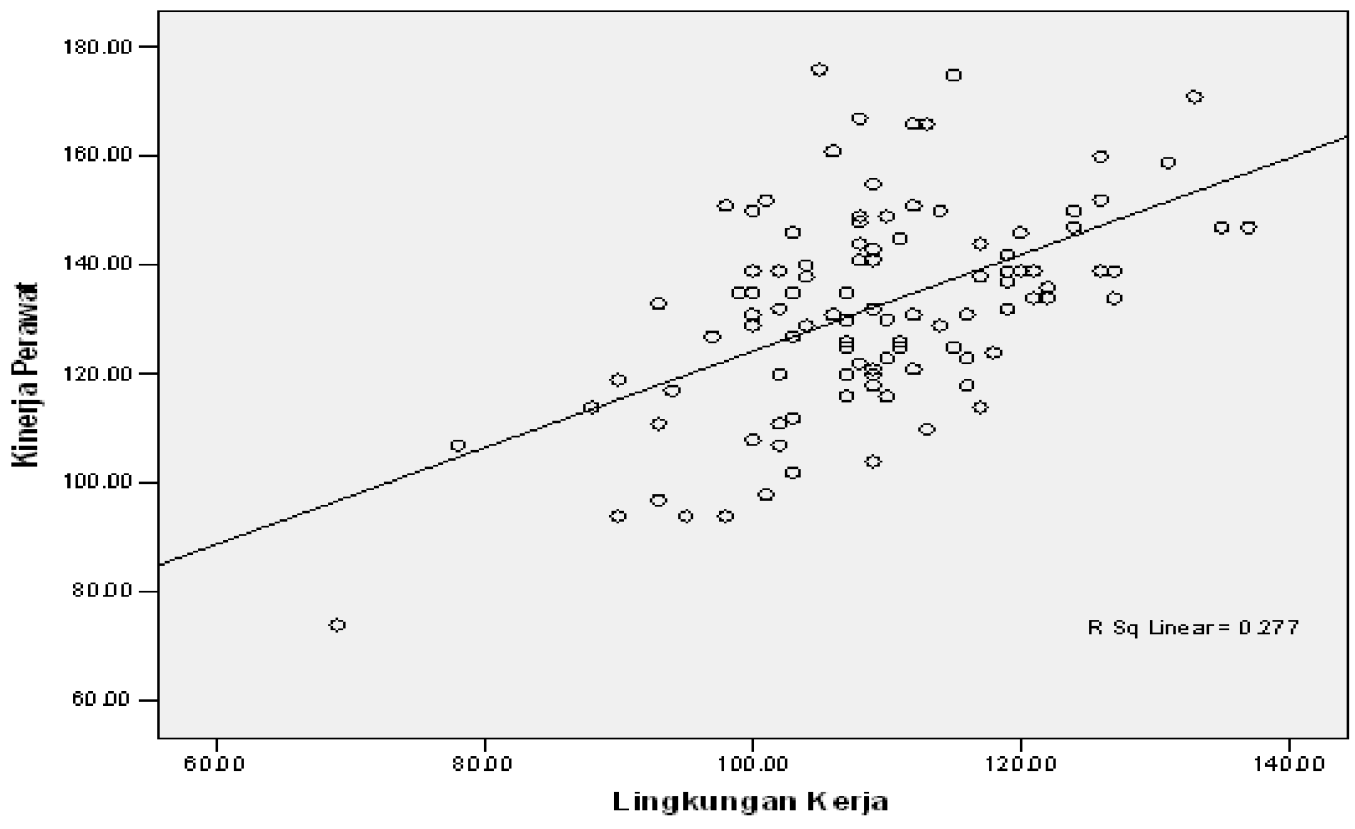


Faktor determinan lainnya yang berhubungan dengan kinerja perawat pelaksana adalah manajemen, kepemimpinan dan budaya yang merupakan faktor organisasional (Gibson, Ivancevich, \& Donelly, 1996; Robbins, 2003).

\section{Kesimpulan}

Komitmen pada organisasi, pada aspek komitmen afektif dan normatif berhubungan dengan kinerja perawat pelaksana di, sedangkan komitmen berkesinambungan tidak berhubungan. Lingkungan kerja perawat; manajemen, kepemimpinan dan budaya.

Kendali terhadap praktik berhubungan dengan kinerja perawat sedangkan kendali terhadap beban kerja dan sumber yang memadai tidak berhubungan dengan kinerja perawat pelaksana. Komitmen Afektif Perawat merupakan faktor paling dominan berhubungan dengan kinerja perawat pelaksana. Penelitian menyarakankan peningkatan komitmen afektif melalui perhatian dan penghargaan terhadap kinerja perawat, kesejahteraaan, program penghargaan, pemilihan perawat berprestasi dan peningkatan lingkungan kerja melalui pemenuhan sarana prasarana, perumusan standar-standar keperawatan (MS, SW, TN).

\section{Referensi}

Allen, N. J., \& Meyer, J. P. (1997). Commitment in the workplace theory research and application. California: Sage Publications.

CCHSA. (2004). National consensus meeting on worklife indicators. Ottawa: Canadian Council on Health Services Accreditation.

Gibson, Ivancevich, \& Donelly. (1996). Organisasi dan manajemen, perilaku, struktur dan proses. Jakarta: Erlangga.
Gillies, D. A.(1994). Nursing management: A system approach (3th Edition). Phyladelphia: WB. Saunders Company.

Hatmoko, T. (2006). Pengaruh kepuasan kerja terhadap komitmen organisasi dan perbedaannya terhadap karakteristik demografi (Tesis, UIN Malang). Diperoleh dari http://lib.uin-malang.ac.id /files/thesis/...ii/ 04920002.ps.

Ilyas, Y. (2004). Perencanaan SDM rumah sakit, teori, metoda dan formula (Tesis, tidak dipublikasikan). Fakultas Kesehatan Masyarakat UI, Depok.

Koentjoro, T. (2007). Regulasi kesehatan di Indonesia. Yogyakarta: CV Andi Offset.

Kramer, M., \& Schmalenberg, C. (2004). Essentials of a magnetic work environment: Part 2. Nursing, 34(7), 44-47. Diperoleh dari http:// journals.lww.com.

Lowe, G. S. (2002). Quality of worklife, indicators for nurse in canadian workshop report. Ottawa: Canadian Nurse Assosiation.

McGillis, L. (2008). Quality work environment: For nurse and patient safety. Diperoleh dari http:// www.nursingresearchonline.com.

McGillis, L., et al. (2003). Indicators of nurse staffing and quality nursing work environment a critical synthesis of the literature. Toronto: The Ontario Ministry of Health \& Long-Term Care. Diperoleh dari www.ontla.on.ca/library/ repository/mon/8000/243365.pdf.

McNeese-Smith, D. K. (2001). A nursing shortage: building organization commitment among nurse. Journal of Healthcare Management, 46 (3), 173-86. Diperoleh dari http://www.ncbi.nlm. nih.gov/pubmed/11372220.

Muliyadi. (2007). Laporan residensi kepemimpinan dan manajemen keperawatan di unit rawat inap Rumah Sakit Tugu Ibu Cimanggis Depok (Laporan, tidak dipublikasikan). FIK UI, Depok.

Istilah tidak ada waktu, jarang sekali merupakan alasan yang jujur,

karena pada dasarnya kita semuanya memiliki waktu 24 jam yang sama setiap harinya.

Yang perlu ditingkatkan ialah membagi waktu dengan lebih cermat.

- George Downing - 